\title{
CHEMICAL, CLINICAL, AND IMMUNOLOGICAL STUDIES ON THE PRODUCTS OF HUMAN PLASMA FRACTIONATION. XL. QUANTITATIVE SEPARATION AND DETERMINATION OF THE PROTEIN COMPONENTS IN SMALL AMOUNTS OF NORMAL HUMAN PLASMA ${ }^{1}$
}

\author{
BY WALTER F. LEVER, FRANK R. N. GURD, EERO UROMA,² RAY K. BROWN, \\ BENJAMIN A. BARNES,4 KARL SCHMID, AND ETHEL L. SCHULTZ
}

(From the University Laboratory of Physical Chemistry Related to Medicine and Public Health, Harvard University, and the Department of Dermatology, Harvard Medical

School, Boston)

(Submitted for publication September 25, 1950; accepted, October 30, 1950)

The need for improved methods for the determination and characterization of the protein components of human blood plasma requires no emphasis. The commonly employed methods for the separation of plasma proteins on the basis of solubility give little detailed information and generally yield poor separations (1). Likewise, the method of electrophoretic analysis, although of unquestioned value, will fail to differentiate between components of widely differing chemical properties and physiological functions if they happen to have the same mobility in an electric field.

The present communication describes the adaptation of Method 10 of plasma fractionation developed by Cohn and his associates (2) for the quantitative estimation of certain of the protein and lipoprotein components in small quantities of normal human plasma. The fractionation is carried out at low temperatures using low concentrations of ethanol and of various salts, resulting in the concentration of each protein component

1 This work was supported by grants from the National Institutes of Health, from industry, funds at the disposal of Harvard University, and by aid from the Harry Helfman Pemphigus Research Fund, the Milton Fund, and other sources. This paper is No. 91 in the series "Studies on the Plasma Proteins" from blood collected by the American Red Cross, on products developed by the University Laboratory of Physical Chemistry Related to Medicine and Public Health, Harvard University.

2 Fellow of the Suomen Kulturri Rabasto, Helsinki. Present address: Department of Serobacteriology, University of Helsinki, Helsinki, Finland.

8 Public Health Research Fellow of the National Institutes of Health.

- Research Fellow of the Life Insurance Medical Research Fund. Present address: Massachusetts General Hospital, Boston, Mass. in an undenatured state almost exclusively in one fraction or another.

In the present system of analysis, samples of 5 $\mathrm{ml}$. of plasma have been separated by filtration into four primary fractions (Figure 1). The concentrations of the serum albumins, $\gamma$-globulins, $\alpha$-lipoproteins, and $\beta$-lipoproteins were measured, together amounting to about $75 \%$ of the total proteins of normal human plasma. Data have also been obtained on the distribution of protein-bound carbohydrate (hexose) among the fractions, but the information is not yet available which would make it possible to calculate the quantities of specific glycoproteins and mucoproteins.

Although the present communication deals with the determination of only four major components of normal plasma, the system of separation has been designed to allow the incorporation of procedures for the isolation and measurement of other components as soon as methods have been worked out. In addition to quantitative analysis of the major protein components in the plasma the proposed method will facilitate the quantitative estimation of trace components, because each fraction contains certain components in higher concentration and in simpler mixtures than whole plasma. Because the proteins are present in various fractions in an unaltered state their biological activities remain unimpaired and can be measured. The method can, furthermore, be used on abnormal plasmas for the quantitative determination of various proteins present in abnormal quantities in the plasma of patients with various diseases. Such quantitative analyses of abnormal plasmas are being carried out at present and will be published in a future communication. Recognition and characterization of pathological proteins, as 
they are present in several diseases, such as multiple myeloma and lupus erythematosus, will be facilitated by this method.

The method has been designed to be as simple and rapid as possible without sacrificing accuracy. All operations, including the separations of precipitates by filtration under vacuum, are carried out in the same cold bath. The separations of six samples of plasma into the four primary fractions can normally be completed in one day by a single worker. The buffer solutions employed were chosen so that for each step stock reagents are added in standard amounts without the necessity of performing tedious $\mathrm{pH}$ adjustments. Accurate separations have been made possible by the use of liberal quantities of buffer solutions to wash the precipitates on the filters. The use of the buffer solutions for washing has the added advantage that small errors in the $\mathrm{pH}$ adjustment at any one step are corrected before subsequent separations are undertaken, and in this way such errors are prevented from accumulating.

\section{SYSTEM OF PLASMA ANALYSIS}

Method 10 of plasma analysis employs a system in which five or more variables are critically controlled: $\mathrm{pH}$, ethanol concentration, ionic strength, protein concentration, temperature and, in some instances, concentration of dipolar ions or of divalent metallic or organic ions. ${ }^{5}$ The conditions at which these variables are fixed, and the components known to be concentrated in the different fractions are given in Figure 1.

In the first step of the procedure, many of the largest and least soluble of the plasma proteins are rendered completely insoluble, and are separated in Fraction I + II + III. The extremely low solubility of the proteins of Fraction I + II + III under the conditions of this separation is due in part to the formation of insoluble salt-like complexes between proteins of opposite net charge (2). The $\gamma$-globulins, most notably, owe their insolubility to combination with $\beta$-lipoproteins and other $\alpha$-globulins and $\beta$-globulins, including caeruloplasmin. In a sense, the components naturally present in the plasma are used as reagents to effect their own quantitative separation. It will be

5 For more detailed information about the role of these variables in protein separations, see Cohn and his colleagues $(2,3)$ and the review by Edsall (4). shown below that wide variations in the concentrations of $\beta$-lipoproteins and $\gamma$-globulins do not interfere with the completeness of the separation of Fraction I + II + III from Fraction IV + V + VI.

The second step of the procedure involves the precipitation in Fraction IV $+\mathrm{V}$ of nearly all the proteins which remained in solution after the initial precipitation of Fraction I + II + III. In this way almost all the plasma proteins are reduced to the more stable solid state within a short time after the beginning of the fractionation. The precipitation is effected by the addition of a small amount of zinc acetate without changing the other variables. The proteins precipitated as insoluble zinc salts include the serum albumins, $\beta_{1}$-metal combining protein, $\alpha_{2}$-glycoproteins, $\alpha_{2}$-mucoproteins, $\alpha$-lipoproteins, iodoproteins, choline esterase and alkaline phosphatase. The zinc salts are readily soluble in distilled water and in a variety of buffer solutions. Analytical determinations for serum albumins and $\alpha$-lipoproteins were usually made on redissolved Fraction $I V+V$, although for certain purposes measurements could be made directly on the solution of Fraction IV $+\mathrm{V}+$ VI. However, for the determination of proteinbound carbohydrate (as hexose) it is necessary to separate Fraction IV $+\mathrm{V}$ and then to precipitate Fraction VI, leaving the free carbohydrate (blood sugar) in solution. Serum albumins are estimated as methemalbumin (5), and the $\alpha$-lipoproteins from determinations of cholesterol and lipid phosphorus.

Fraction VI, which remains in solution after the precipitation of Fraction IV $+V$, contains traces of the proteins of Fraction IV $+V$, and in addition an $\alpha_{1}$-acid glycoprotein, small amounts of $\alpha_{2}$-globulins and $\beta_{1}$-globulins, as well as other small proteins and peptides, urea, and glucose. The protein and certain peptide constituents of this fraction are precipitated by the addition of barium acetate and an increase in the concentration of ethanol.

The third step of the procedure serves to extract from Fraction I + II + III almost all the $\gamma$-globulins in a nearly pure form, as judged by electrophoretic analysis of Fraction II. To accomplish this separation, it was found necessary to add the dipolar ion glycine to decompose the complexes in which the $\gamma$-globulins are held. The ethanol concentration of $15 \%$ and the low ionic strength used 


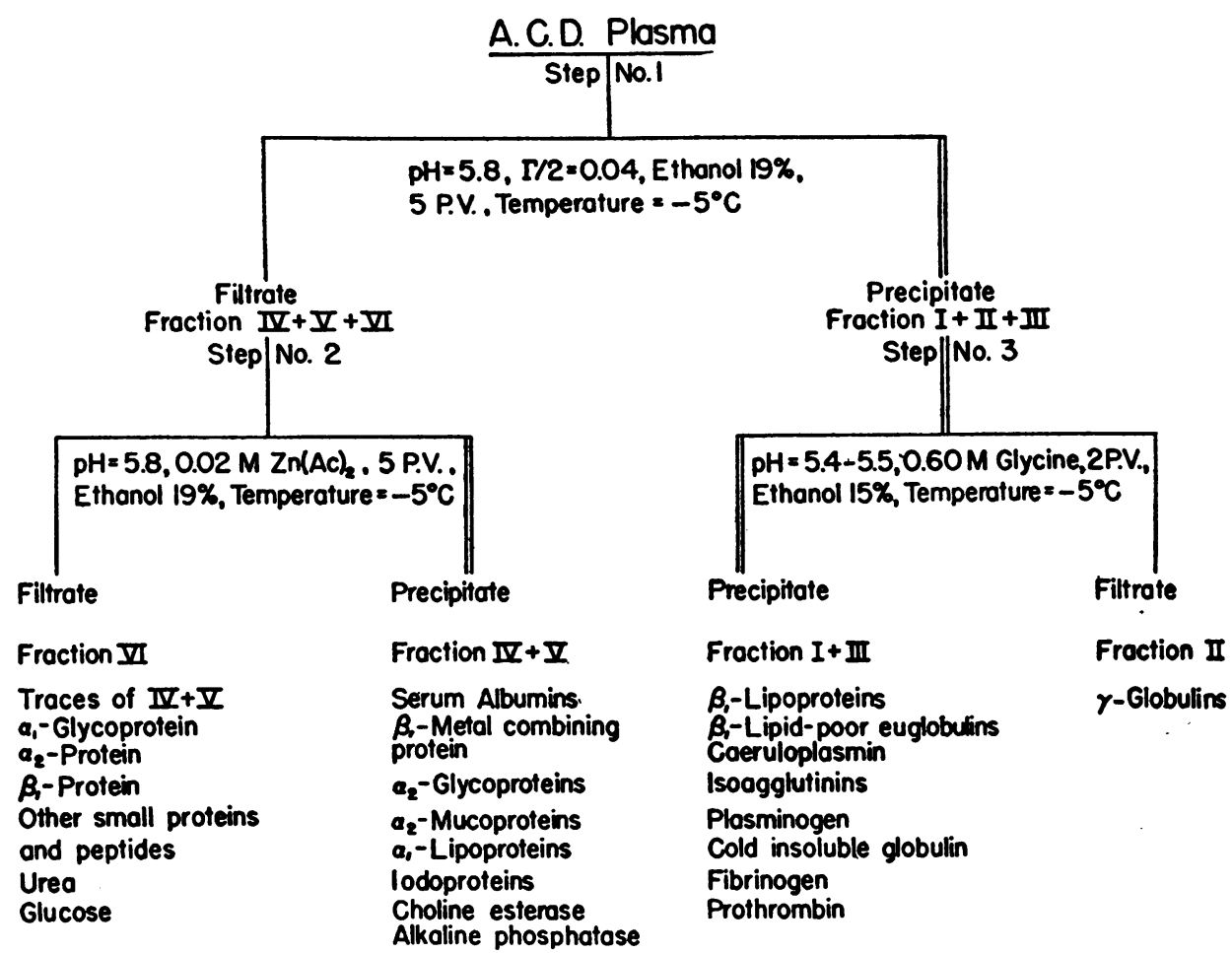

Fig. 1. Protein Components Concentrated in the Four Primary Fractions

during the extraction prevents solution of more than traces of $\beta$-globulins.

The yield of protein in Fraction II is obtained by direct measurement with the biuret reaction on an aliquot of the solution. When concentration of the extract is required prior to electrophoretic, ultracentrifugal, or other analyses, the $\gamma$-globulins are quantitatively reprecipitated by the addition either of sodium tartrate or of a mixture of sodium sulfate and zinc acetate, accompanied by an increase in concentration of ethanol. The use of the divalent anions makes it unnecessary to increase the ethanol concentration to the point where glycine would precipitate along with the $\gamma$-globulins. The precipitates obtained in this way are readily soluble in distilled water or a wide variety of salt solutions.

Fraction I + III, which remains insoluble after the extraction of the $\gamma$-globulins, contains $\beta$-lipoproteins, caeruloplasmin, isoagglutinins, most of the components concerned with blood clotting, and a number of $\alpha$-globulins and $\beta$-globulins whose characteristics are not yet well understood. The use of the technique of fractional extraction for the removal of the $\gamma$-globulins serves to keep the components of Fraction I + III insoluble from the time that they are precipitated in the initial step of the procedure until they are redissolved for analysis at the very end of the operation. In the solid state these components are quite stable and are protected from various changes, chemical and enzymatic, which occur rapidly in solution. The yield of $\beta$-lipoproteins in Fraction I + III is estimated from cholesterol and lipid phosphorus determinations on the redissolved fraction.

\section{MATERIALS AND METHODS \\ Collection of Blood}

Blood was obtained from male subjects by venipuncture with a syringe containing $1.5 \mathrm{ml}$. of acid citrate dextrose solution (A.C.D.) for each $8.5 \mathrm{ml}$. of blood to be drawn. The blood cells were removed by centrifugation to obtain the plasma, designated as "A.C.D. plasma," which was used for the separations and analyses." The acid citrate dextrose solution contained per liter $26.7 \mathrm{~g}$. trisodium citrate $\left(5 \frac{1}{2} \mathrm{H}_{2} \mathrm{O}\right), 8.0 \mathrm{~g}$. citric acid monohydrate, and $22 \mathrm{~g}$. dextrose. At the same time, for the purpose of a reference determination of total protein, approximately $5 \mathrm{ml}$. of blood were drawn with a dry syr-

- The tendency of the clot to entrap certain proteins to a larger extent than others prompted our decision not to apply the separation method to serum (6). 
inge, and placed in a tube containing a small amount of heparin powder.

\section{Apparatus}

The fractionation was carried out in a $-5^{\circ} \mathrm{C}$. bath containing $50 \%$ by volume of ethanol, provided with an effective stirrer, and deep enough to submerge the filtration apparatus to the required depth. ${ }^{7}$ For the filtration a sintered glass filter cup with a maximum porosity of 14 microns and a capacity of $60 \mathrm{ml}$. was used.8, 9 This filter cup was connected to a $100 \mathrm{ml}$. round-bottom collecting tube by a two-hole rubber stopper. The glass stem of the filter cup entered the collecting tube through one hole of the stopper. A suction system was connected through the other hole of the stopper. The filter cups and attached collecting tubes were held in the bath by a rigid amount of sufficient size to accommodate 12 such filtration units. The availability of 12 filtration units allowed the processing of six specimens of blood plasma in one day.

A water aspirator was used to obtain vacuum. A regulating column of mercury was employed to control the vacuum, ${ }^{10}$ and a large carboy was placed in the suction line to minimize pressure variations due to the aspirator. A steady pressure of $38 \mathrm{~cm}$. of mercury was found most effective.

Adequate cleaning of the glass filter cups as soon as possible after use is important. They were first washed with soap and water. Thereafter, saturated borax solution, dilute hydrochloric acid, distilled water, and $95 \%$ alcohol were drawn successively through the filters under negative pressure provided by a water aspirator. (If the filters were still plugged, several lots of a $2 \%$ aqueous solution of duponol were drawn through the filters prior to the use of the saturated borax solution.) It was found inadvisable to use any one glass filter cup for more than ten runs.

\section{Reagents}

All reagents were freshly prepared from stock solutions at room temperature and precooled to $-5^{\circ}$ (or the freezing point of the mixture) before use. The stock solu-

7 A 50 gallon capacity cold bath supplied by the American Instrument Company, Silver Spring, Md. was used. The internal dimensions are $21.75 \times 37.75 \times 15$ inches, and the temperature was adjustable to within $0.5^{\circ} \mathrm{C}$. over a temperature range between room temperature and $-29^{\circ}$.

8 These filter cups are made by the Corning Glass Works, and were obtained from Macalaster-Bicknell Co., Cambridge, Mass. Filter cups with a maximum porosity of 14 microns are marked $M$; those with a maximum porosity of 5 microns are marked $\mathrm{F}$.

- Very rarely, it was found that the precipitate formed by the initial precipitation would pass through the filter. In such instances a sintered glass filter cup with a maximum porosity of 5 microns was used to obtain a clear filtrate.

10 In recent work, satisfactory vacuum regulation has been obtained with a Cartesian Manostat No. 6, supplied by Emil Greiner Co., 22 N. Moore St., New York, N. Y. tions were made with C.P. grade reagents without further purification.

Reagent $A$ contained $250 \mathrm{ml} .95 \%$ ethanol, and $2.4 \mathrm{ml}$. of sodium acetate buffer, and water to make $1 \mathrm{~L}$. The stock sodium acetate buffer consisted of $200 \mathrm{ml}$. of $4 \mathrm{M}$ sodium acetate and $400 \mathrm{ml}$. of $10 \mathrm{M}$ acetic acid per L. This buffer diluted with distilled water 80 times had a $\mathrm{pH}$ of $4.00 \pm 0.02$ in a glass electrode at $25^{\circ}$ ([3] footnote 68 ).

Reagent $A^{\prime}$ contained $200 \mathrm{ml}$. of $95 \%$ ethanol, $40 \mathrm{ml}$. of $1 \mathrm{M}$ sodium acetate, $3.5 \mathrm{ml}$. of $1 \mathrm{M}$ acetic acid, and water to make $1 \mathrm{~L}$. The $\mathrm{pH}$ was $5.80 \pm 0.05$.

Zinc Reagent contained $54.8 \mathrm{~g}$. of zinc acetate dihydrate which was first dissolved in about $500 \mathrm{ml}$. of water; to this solution $200 \mathrm{ml}$. of $95 \%$ ethanol were added, and then water to make $1 \mathrm{~L}$. The solution should be kept at refrigerator temperature since at room temperature undesirable deposition of insoluble material occurs. The $\mathrm{pH}$ of this solution was $6.5 \pm 0.1$.

Barium Reagent contained 10.22 g. barium acetate, 640 ml. 95\% ethanol, and water to make $1 \mathrm{~L}$.

Reagent B contained $150 \mathrm{ml}$. 95\% ethanol, $45 \mathrm{~g}$. glycine, $3.8 \mathrm{ml} .1 \mathrm{M}$ sodium acetate, $2.6 \mathrm{ml} .1 \mathrm{M}$ acetic acid, and water to make $1 \mathrm{~L}$. The $\mathrm{pH}$ was $5.20 \pm 0.02$.

Reagent $B^{\prime}$ contained $150 \mathrm{ml}$. of $95 \%$ ethanol, $45 \mathrm{~g}$. glycine, $5 \mathrm{ml}$. of $1 \mathrm{M}$ sodium acetate, $1.8 \mathrm{ml} .1 \mathrm{M}$ acetic acid, and water to make $1 \mathrm{~L}$. The $\mathrm{pH}$ was $5.40-5.45$.

Citrate Reagent contained $9.0 \mathrm{~g}$. sodium chloride, $7.1 \mathrm{~g}$. trisodium citrate $\left(51 / 2 \mathrm{H}_{2} \mathrm{O}\right)$, and water to make $1 \mathrm{~L}$.

Tartrate Reagent contained $13.8 \mathrm{~g}$. disodium tartrate, $475 \mathrm{ml} .95 \%$ ethanol, and water to make $1 \mathrm{~L}$.

Sulfate Reagent contained $8.5 \mathrm{~g}$. anhydrous sodium sulfate, $4.4 \mathrm{~g}$. zinc acetate dihydrate, $362 \mathrm{ml}$. of $95 \%$ ethanol, and water to make $1 \mathrm{~L}$.

\section{Separation Procedures}

Step No. 1. The initial precipitation of Fraction I+ II + III, leaving Fraction IV + V + VI in solution, was performed as follows. Two ml. of precooled Reagent A were placed in the sintered glass filter cup which was immersed in the cold bath within $1 \mathrm{~cm}$. of the lip. Five ml. of A.C.D. plasma precooled to $0-2^{\circ}$ were added dropwise with stirring, followed by $18 \mathrm{ml}$. of Reagent A again added dropwise with good stirring.11 After the addition was completed, the mixture was stirred for five minutes, and allowed to stand for 10 to 15 minutes before the vacuum was applied. The filtration required about 40 minutes.

The precipitate was then washed 12 by resuspending it

11 If the plasma was placed in the filter cup before any reagent was added, it was found that some of the plasma penetrated the pores of the filter before precipitation occurred. This resulted in considerable slowing of the filtration due to freezing of some of the plasma in the filter pores, and cloudiness of the filtrate due to the escape of some precipitable proteins through the filter. On the other hand, if larger volumes of reagent were added first, the plasma would be exposed initially to excessively acid conditions.

12 Without washing, appreciable quantities of the soluble proteins belonging to Fraction IV + V + VI remained 
in $25 \mathrm{ml}$. of Reagent $\mathrm{A}^{\prime}$. The precipitate was at first stirred to a thick uniform paste with a small amount of the reagent before the rest of the reagent was added with constant stirring. The collecting tube containing Fraction IV + V + VI was left in place to receive the washings. The vacuum was applied without delay. The filtration required about 30 minutes.

Step No. 2. As soon as the filtration of the washing had been completed, the filtration apparatus was momentarily removed from the cold bath, the receiving flask transferred to a wire basket suspended in the cold bath, and a fresh receiving flask attached in its place. The filtration apparatus was immediately reimmersed. To the solution of Fraction IV + V + VI in the first receiving flask were added $4 \mathrm{ml}$. of the Zinc Reagent, causing copious precipitation. The resulting suspension was allowed to stand for 15 to 30 minutes in the cold bath (overnight was found permissible), and was then poured into a new filter cup which differed from the first only in that the maximum porosity was 5 microns instead of 14 microns. The last traces of the suspension in the first receiving flask were washed into the filter cup with the aid of a few ml. of $0.02 \mathrm{M}$ zinc acetate dissolved in $19 \%$ ethanol. Filtration was carried out as before. The precipitate remaining on the filter constituted Fraction IV + $\mathrm{V}$, and was redissolved either in $0.15 \mathrm{M}$ sodium chloride or $0.02 \mathrm{M}$ sodium citrate to a volume of $5 \mathrm{ml}$. for the purpose of analysis.

The filtrate, Fraction VI, contained so little protein that frequently it was not subjected to further isolation procedures. When desired, the proteins of Fraction VI were precipitated by the addition of an equal volume of Barium Reagent, and separated as before by filtration through a glass filter with a maximum porosity of $14 \mathrm{mi}$ crons. The precipitate was washed with two $10 \mathrm{ml}$. portions of the following reagent: $5.47 \mathrm{~g}$. barium acetate monohydrate, $4.39 \mathrm{~g}$. zinc acetate dihydrate, $421 \mathrm{ml}$. 95\% ethanol, and water to make $1 \mathrm{~L}$. The precipitate was then dissolved in a mixture of $0.5 \mathrm{ml}$. Citrate Reagent and $4.5 \mathrm{ml}$. distilled water, and the resulting solution drawn through the filter. The filter was washed through with $2 \mathrm{ml}$. of $0.1 \mathrm{M}$ sodium sulfate solution and the washings added directly to the dissolved Fraction VI. The Fraction VI solution was made up to $10 \mathrm{ml}$. with distilled water, and placed in a refrigerator for 30 minutes to allow the precipitate of barium sulfate to form. The precipitate was removed by a short centrifugation in an ordinary laboratory centrifuge before aliquots of the clear solution were taken for biuret and hexose analyses. If only the biuret determination was required, it was sufficient to dissolve the precipitate of Fraction VI in the diluted Citrate Reagent.

Step No. 3. The third step of the separation procedure involved the extraction of Fraction II from Fraction occluded in Fraction I+ II + III and appeared subsequently in Fraction II, resulting in contamination of the $\gamma$-globulins in Fraction II to the extent of about $20 \%$ with albumins. Carrying out the initial precipitation at higher dilutions did not circumvent this difficulty as satisfactorily as did the introduction of the washing step.
I + II + III, leaving Fraction I + III as residue. This separation was carried out concurrently with Step No. 2. Fraction I + II + III in the original filter cup was resuspended in $25 \mathrm{ml}$. of Reagent B. As in the previous washing with Reagent $A^{\prime}$, only about $1 \mathrm{ml}$. of Reagent $B$ was added at first, and a thick, uniform paste was prepared. Thereafter, the rest of the reagent was added slowly with constant stirring. The suspension was allowed to stand for one hour with occasional stirring before the vacuum was applied. The filtration required approximately two hours.

The residue was then washed by resuspending it in $10 \mathrm{ml}$. of Reagent B'. Filtration was started without delay. The washings were filtered into the same collecting tube which contained Fraction II. This filtration required only about 10 minutes.

The residue on the filter cup, representing Fraction I+ III, was removed as completely as possible with a small stainless steel spatula. Three small portions of Citrate Reagent were drawn through the filter in order to remove any protein remaining in the pores. These effluents were used to dissolve the paste previously removed with the spatula, and the whole was made up to $5 \mathrm{ml}$. with $\mathrm{Ci}$ trate Reagent and taken for analysis. Allowing the suspension to warm slightly by exposing it to room temperature facilitated solution.13

Reprecipitation of the protein components of Fraction II was effected by adding $35 \mathrm{ml}$. of Sulfate Reagent to the Fraction II filtrate and washings. If for subsequent assays the presence of zinc ions was undesirable, and their removal or neutralization inconvenient, $35 \mathrm{ml}$. of Tartrate Reagent was substituted for the Sulfate Reagent. ${ }^{14}$ In either case, the precipitate was allowed to form for one hour before removal by filtration in the cold bath through a glass filter cup with a maximum porosity of 14 microns. The filtration required about 15 minutes. The precipitated Fraction II was dissolved and made up to $5 \mathrm{ml}$. with distilled water or $0.15 \mathrm{M}$ sodium chloride.

\section{Analytical Methods}

Nitrogen determinations were carried out by the micro-Kjeldahl method. Non-protein nitrogen (NPN) was determined after precipitation of the proteins with $10 \%$ trichloracetic acid.

Biuret determinations were carried out by a modification of the method of Mehl (7) in which each series of readings was standardized against a standard preparation of normal human serum albumin ([6] footnote 14).15 Determinations were made by diluting each aliquot to $10 \mathrm{ml}$. with $0.15 \mathrm{M}$ sodium chloride before addition of 1

$18 \mathrm{~A}$ small amount of material often failed to dissolve.

14 When the Tartrate Reagent was employed, precipitation of the proteins was only about $95 \%$ complete, but could be made quantitative by carrying out the filtration at $-8^{\circ}$.

15 Crystalline bovine serum albumin, obtainable from Armour and Co., Chicago, Ill., may be used in place of the human serum albumin without the need of applying any corrections due to the species difference. 
ml. of the biuret reagent. The reagent was prepared as follows. To a solution of $20.5 \mathrm{~g}$. cupric chloride dihydrate in $300 \mathrm{ml}$. of water, $150 \mathrm{ml}$. of ethylene glycol was added, followed by $300 \mathrm{~g}$. of sodium hydroxide in aqueous solution, and the whole was diluted to $1 \mathrm{~L}$. with water and transferred to a large Erlenmeyer flask covered with a watch-glass, and heated for four hours on a steam bath. The solution was filtered after cooling. Color development was allowed to proceed for 20 to 30 minutes before measurement in a Leitz photoelectric colorimeter set at $550 \mathrm{~m} \mu$. (Klett and Coleman instruments have also been employed.)

Lipid analyses were carried out on ethanol-ether extracts prepared as follows. The protein solutions were added to about 20 volumes of ethanol-ether mixture (3:1 by volume), heated to boiling, cooled, and made up to 25 volumes. Aliquots were taken after filtration for the determination of total cholesterol and lipid phosphorus. Total cholesterol was determined by the method of Bloor, Pelkan and Allen (8). The photoelectric colorimeter was set at $640 \mathrm{~m} \mu$. Lipid phosphorus was determined by the method of Fiske and SubbaRow (9) following the ashing procedure of Gortner (10). Color intensity was measured at $640 \mathrm{~m} \mu$. The factor 25.0 was used to convert lipid phosphorus to phospholipid.

Serum albumin determinations were carried out by the hemin-binding method of Rosenfeld and Surgenor (11).

Hexose determinations were made according to a modification of the method of Sørensen and Haugaard (12) introduced by Friedmann (13). The reaction mixture contained $1 \mathrm{ml}$. of protein solution, $2.5 \mathrm{ml}$. of $1.6 \%$ orcinol in $50 \%$ sulfuric acid (by volume) and $15 \mathrm{ml}$. of $60 \%$ sulfuric acid. Color was developed by heating for 20 minutes at $80^{\circ}$, cooling in ice in the dark for 20 minutes, then standing at room temperature in the dark for 30 minutes. The color was measured at $445 \mathrm{~m} \mu$. An equimolar mixture of galactose and mannose was used to prepare the standards included in each series of determinations.

Fibrinogen determinations (clottable protein) were made according to the method of Morrison (6).

Determinations of $p H$ were carried out in the glass electrode at $25^{\circ}$, using $1 \mathrm{ml}$. of reagent solution or of protein suspension mixed with $4 \mathrm{ml}$. of $0.02 \mathrm{M}$ sodium chloride.

Electrophoretic analysis of plasma and of the various fractions was used for supplementary characterization of the various fractions. The measurements were carried out in a sodium diethyl barbiturate-sodium citrate buffer at $\mathrm{pH} 8.6$ and an ionic strength of 0.1 by the standard procedure employed in this laboratory (14). The buffer contained per L. $11.05 \mathrm{~g}$. of barbital, $2.45 \mathrm{~g}$. of sodium citrate $\left(2 \mathrm{H}_{2} \mathrm{O}\right)$ and $50 \mathrm{ml}$. of $1 \mathrm{~N} \mathrm{NaOH}$.

Determinations of dry weight, as a method of total protein determination, were carried out as follows: ${ }^{16}$

A length of cellophane tubing 0.5 inch in diameter was weighed, soaked in water, and a knot was tied in one end.

16 We are indebted to Dr. M. A. Lauffer, University of Pittsburgh, for the general description of this method.
A known volume of the solution to be analyzed containing 100 to $300 \mathrm{mg}$. protein was added from a carefully wiped pipette introduced well down inside the bag. A small volume of distilled water was used to wash down any protein adhering near the opening of the bag. The bag was tied with sufficient slack to avoid squeezing the protein solution above the knot and to allow room for expansion on freezing. At the same time an equal length of tubing was tared and filled with an equal volume of distilled water. The two bags were dialyzed for three to four days against several daily changes of distilled water. The bags were then frozen rapidly by immersion in $95 \%$ ethanol cooled by a bath of dry ice in ethanol. The frozen bags were immediately transferred to a vacuum oven connected to a dry ice-ethanol trap and vacuum pump. The temperature of the oven was immediately raised to $75^{\circ}$. Constant weight was reached within 12 hours.

The initial-weight of the tubing containing the unknown sample was corrected on the assumption that it underwent the same proportionate decrease in weight on drying as the control.

Neutralization or removal of zinc or barium ions added in performing the separations was found necessary for some assays. This was accomplished by one of the following methods. For many purposes it was found sufficient to neutralize the effect of the metals by the addition of sodium citrate or the more effective ethylenediaminetetraacetate ${ }^{17}$ without actually removing the metals from the solution. When complete removal of the added cations was desirable, Fraction IV + V, or VI, was dissolved in water and passed through a cationic exchange resin column at $0^{\circ}$. A column of Dowex-50 exchange resin ${ }^{18}$ $10 \mathrm{~cm}$. in height and $2 \mathrm{~cm}$. in diameter resulted in removal of usually more than $99 \%$ of the added divalent metals when the protein solution was allowed to pass through at the rate of $0.25 \mathrm{ml} . / \mathrm{cm}^{2} / \mathrm{min}$. Since it is necessary that the resin column be covered with liquid at all times, liberal quantities of distilled water must be passed through the column to displace the protein solution. When removal of the last traces of metals was not required, it was sufficient to stir the protein solution directly with the resin and to wash by decantation.

\section{Analysis of Plasma and Separated Fractions}

The analytical procedures were applied to the various fractions as follows :

17 The trisodium salt of ethylenediaminetetraacetic acid was supplied as Sequestrene NA3 by the Alrose Chemical Co., Providence, R. I.

18 The cationic exchange resin, Dowex-50 (plant grade, 30-50 mesh) may be obtained on the sodium cycle from National Aluminate Corp., Chicago 38, IIl., under the name Nalcite HCR. The only preparation necessary consisted in washing the resin by swirling in a flask with successive volumes of hot distilled water and allowing it to settle. This process was continued until the water above the settled resin was clear. The resin may be reactivated by treating for 15 minutes with $0.15 \mathrm{M}$ sodium chloride, followed by thorough washing with distilled water. 


\section{Plasma}

a) Total protein was calculated by applying the factor 6.73 to the value for protein nitrogen (15).19 To correct the values obtained on the A.C.D. plasma (i.e., plasma with acid citrate dextrose as anticoagulant) to absolute values, the nitrogen determination was repeated on plasma from heparinized blood drawn at the same time. ${ }^{20}$ The factor ( $N$ in heparinized plasma/N in A.C.D. plasma) has been applied to all data for A.C.D. plasma and the various fractions. ${ }^{21}$

b) Total cholesterol and lipid phosphorus were determined on an aliquot of $2 \mathrm{ml}$.

c) Fibrinogen was determined on an aliquot of $1 \mathrm{ml}$.

d) Serum albumin was occasionally determined on an aliquot of $1 \mathrm{ml}$. made up to $125 \mathrm{ml}$. with sodium phosphate buffer of $\mathrm{pH} 7.3$ and ionic strength 0.3 .

\section{Fraction $I V+V$}

a) Total protein was determined by the biuret reaction on an aliquot of $0.5 \mathrm{ml}$.

b) Total cholesterol and lipid phosphorus were determined on an aliquot of $2 \mathrm{ml}$. The value obtained for total cholesterol was converted into the value for $a$-lipoproteins by multiplying by $6.25 .^{22}$

c) Serum albumin was determined on an aliquot of 1

19 In the usage of this Laboratory, "total protein" is synonymous with "total non-dialyzable solids." This practice allows a more direct interpretation of electrophoretic and ultracentrifugal data than the use of some purely arbitrary value such as $\mathrm{N} \times 6.25$, since the contribution of the lipids to the refractive index of plasma or of the fractions is only a little less than that of a corresponding weight of protein (14). The theoretical justification of such a practice is that in normal fasting plasma all, or almost all, of the lipids appear to be present in the form of well-defined lipoproteins, and tally should be kept of the whole of such components rather than only of their peptide part $(16,17)$. The same argument applies to protein-bound sugar. The factor 6.73 is most accurately employed with pooled normal plasma but obviously will not, in general, be correct for highly abnormal plasmas. For this latter purpose, individual determinations of dry weight are recommended.

20 The use of heparin as anticoagulant for the plasma to be fractionated was avoided on the advice of Dr. Alfred Chanutin who had observed that in such a case Fraction I + II + III tended to clot readily. The possibility that heparin would affect the solubility behavior of various plasma proteins was also a deterrent to its use.

21 The value of this factor varied between 1.10 and 1.30 , with an average of about 1.20. Comparison with the value of 1.32 which would be predicted (for a plasmacrit of 0.55 ) on the basis of simple dilution with the acid citrate dextrose solution shows a varying effect of the A.C.D. solution on the red cell volume.

22 For this calculation the percentage of cholesterol in the a-lipoproteins was taken as 16 ([3] Table VIII, Fraction IV-1, 1). ml. made up to $100 \mathrm{ml}$. with sodium phosphate buffer of pH 7.3 and ionic strength 0.3 .

d) Hexose was determined on an aliquot of $1 \mathrm{ml}$.

\section{Fraction VI}

a) Total protein was determined by the biuret reaction on an aliquot of $5 \mathrm{ml}$.

b) Hexose was determined on an aliquot of $2 \mathrm{ml}$.

\section{Fraction $I V+V+V I$}

Occasionally the solution of Fraction IV $+\mathrm{V}+\mathrm{VI}$ was analyzed as a whole for total protein, total cholesterol, lipid phosphorus and serum albumin before Step No. 2 was carried out. The presence of the free carbohydrate (glucose) of plasma in Fraction IV $+\mathrm{V}+\mathrm{VI}$ made impossible hexose determinations before separation of the glucose by washing Fraction VI.

\section{Fraction $I I$}

a) Total protein was determined by the biuret reaction on an aliquot of $5 \mathrm{ml}$. of the extract of Fraction II before precipitation. Five $\mathrm{ml}$. of Reagent $\mathrm{B}^{\prime}$ were included in the standard and blank biuret reagent mixtures to allow for the small enhancement of optical density due to the formation of copper-glycine complexes. Alternatively, $2 \mathrm{ml}$. of the redissolved Fraction II solution were used without the necessity of making allowance for the interference of glycine.

b) Total cholesterol and phospholipid were determined on an aliquot of $3 \mathrm{ml}$. of the redissolved Fraction II.

\section{Fraction $I+I I I$}

a) Total protein was determined by the biuret reaction on an aliquot of $1 \mathrm{ml}$.

b) Total cholesterol and lipid phosphorus were determined on an aliquot of $2 \mathrm{ml}$. The value obtained for total cholesterol was converted into the value for $\beta$ lipoproteins by multiplying by $2.86 .{ }^{23}$

For the calculation of the total protein in Fraction I + III, the value for the biuret determination was corrected by the addition of the quantity (g. per $100 \mathrm{ml}$. of cholesterol) $\times 2.14$, based on the presence of $75 \%$ total lipids in the $\beta$-lipoproteins (17). On the average such a correction gave a ratio of total protein to biuret value of 1.27. This calculation may be expected to fail when applied to the fraction separated from lipemic plasma or plasma containing highly atypical lipoproteins. The necessity for including the lipid correction was shown by comparison of the value for total protein obtained by dry weight with the biuret value. For a typical Fraction I + III, the ratio of dry weight to biuret value was 1.19 , in contrast to ratios of 1.02 and 0.97 for Fractions IV $+V$ and II, respectively. Because of the small deviations, it

${ }^{23}$ For this calculation the percentage of cholesterol in the $\beta$-lipoproteins was taken as 35 , since it was found that the cholesterol determination employed in this procedure yielded $35 \%$ cholesterol instead of the average of $30.9 \%$ obtained with a more accurate procedure (16). 


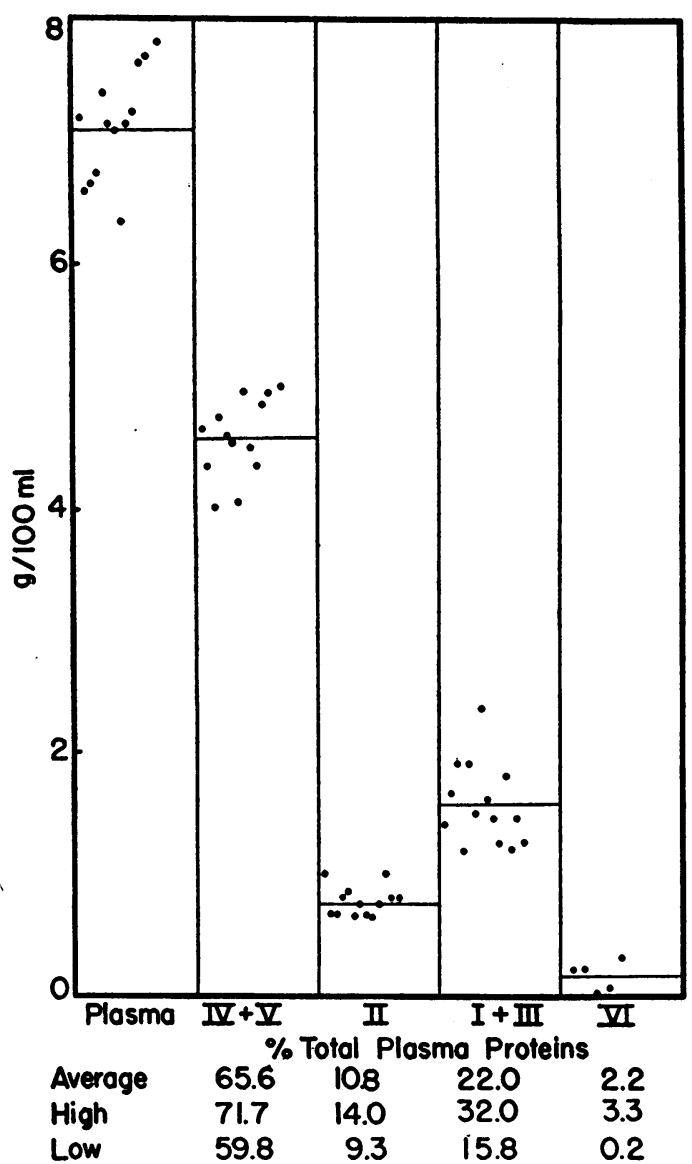

Fig. 2. Concentration of Total Protein in Plasma and in the Four Primary Fractions

has been considered unnecessary for routine purposes to apply corrections to the total protein values obtained by the biuret determinations on Fraction IV $+\mathrm{V}$ and II.

\section{RESULTS}

\section{Protein Distribution}

Representative data for the concentration of total protein in plasma and in each fraction are given in Figure 2. The average for each group of data is indicated by a horizontal line. Average and extreme high and low values for the per cent of the total plasma proteins in each fraction are shown at the bottom of the figure.

\section{Cholesterol and Phospholipid Distribution}

The distributions of cholesterol and phospholipid among the fractions are shown in Figure 3. The mole ratio of cholesterol to lipid phosphorus among the fractions is presented in Table I. The quanti- ties of cholesterol and phospholipid separated in each fraction were slightly more variable than the total protein (Figure 2); yet the constancy of the distribution was still striking. Perhaps most interesting was the finding of the fairly constant and yet widely differing mole ratios of cholesterol to lipid phosphorus in Fractions IV $+V$ and $I+$ III, associated with $\alpha$-lipoproteins and $\beta$-lipoproteins respectively (Table I). ${ }^{24}$ Fraction IV + V, containing the $\alpha$-lipoproteins, had significantly larger amounts of phospholipids than of cholesterol; whereas in Fraction I + III, containing the $\beta$-lipoproteins, the amount of cholesterol was greater than that of phospholipids. Some of the other contrasting properties of these two groups of lipoproteins have been described elsewhere (17). The high ratio of cholesterol to phospholipid found in Fraction II is characteristic of neither of the main groups of $\alpha$-lipoproteins or $\beta$-lipoproteins, and invites further study to establish the form in which these lipids are present in Fraction II.

The proportion of the total cholesterol in the esterified form was determined on the fractions of six samples of plasma by the method of Schoenheimer and Sperry (18): The average values for the per cent esterified cholesterol were $73.4 \%$, $70.1 \%$ and $76.7 \%$ for plasma, Fraction I + III, and Fraction IV $+\mathrm{V}$, respectively. These results confirm the essential constancy of the re-

24 The mole ratio in Fraction I + III, 2.31, is in agreement with the value of 2.11 calculated from the data of Oncley, Gurd and Melin (16) for the preparations of purified $\beta$-lipoproteins separated from large pools of normal plasma. The present values would have been slightly lower if the more tedious analytical procedure (involving hydrolysis of cholesterol esters) used by Oncley and his associates had been employed.

TABLE I

Mole ratio of total cholesterol to lipid phosphorus in plasma fractions Mole ratio cholesterol/lipid P

\begin{tabular}{c|c|c|c|c}
\hline \hline & \multicolumn{3}{|c|}{ Fraction } & Plasma \\
\cline { 2 - 4 } & I + III & II & IV + V & \\
\hline & 2.21 & 5.75 & 1.01 & 1.52 \\
& 2.33 & 4.10 & 0.72 & 1.63 \\
& 2.50 & 3.88 & 0.80 & 1.70 \\
& 2.31 & 3.90 & 0.72 & 1.72 \\
& 2.18 & 5.88 & 0.78 & 1.88 \\
& 2.31 & 4.70 & 0.81 & 1.69 \\
\hline
\end{tabular}




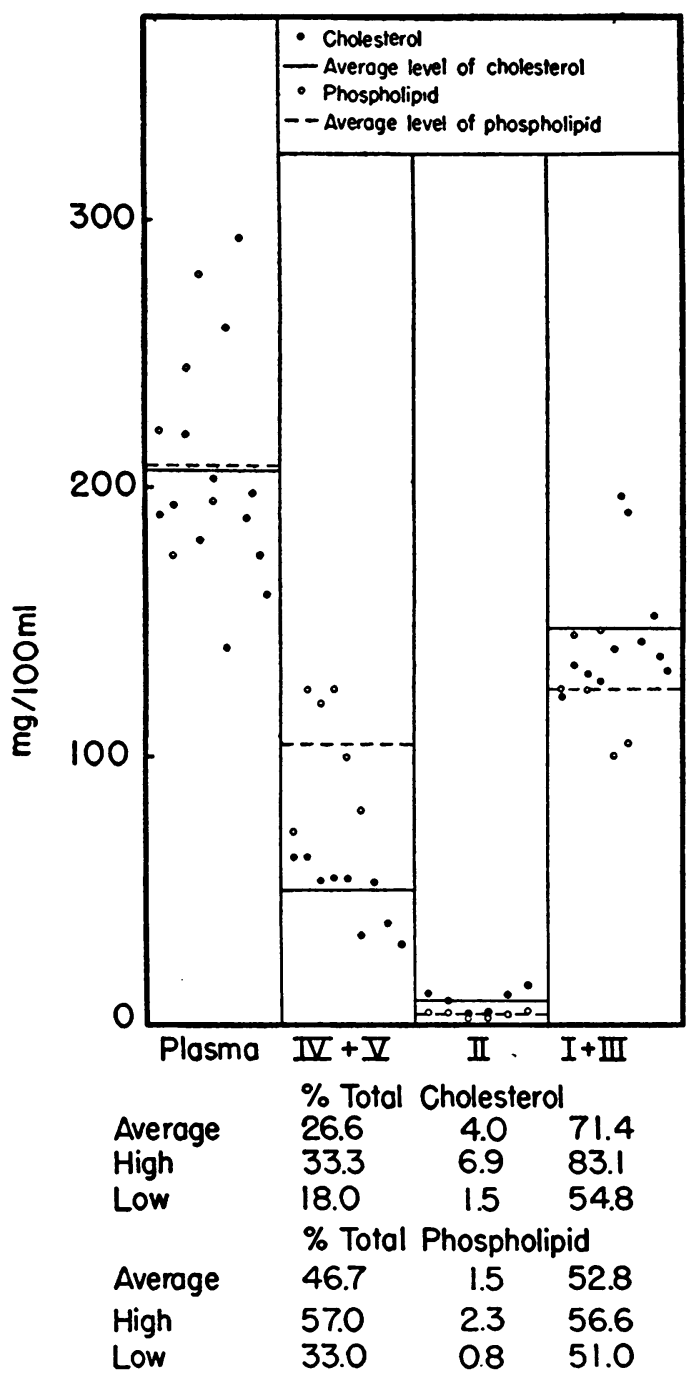

Fig. 3. Distribution of Cholesterol and PhosphoLIPID AMONG THE FRACTIONS

lationship between esterified and unesterified cholesterol in the major lipoprotein fractions, first shown in fractions prepared by a forerunner of the present method (3). ${ }^{25}$

Fraction VI was found to contain at most immeasurably small traces of cholesterol and phospholipid.

\section{Carbohydrate Distribution}

The distribution of protein-bound carbohydrate (hexose) among the protein fractions is presented in Figure 4. The lack of information about the

\footnotetext{
${ }^{25}$ Personal communications from Drs. W. M. Sperry, M. Melin, and A. Chanutin. For more recent studies, see Pearsall and Chanutin (19).
}

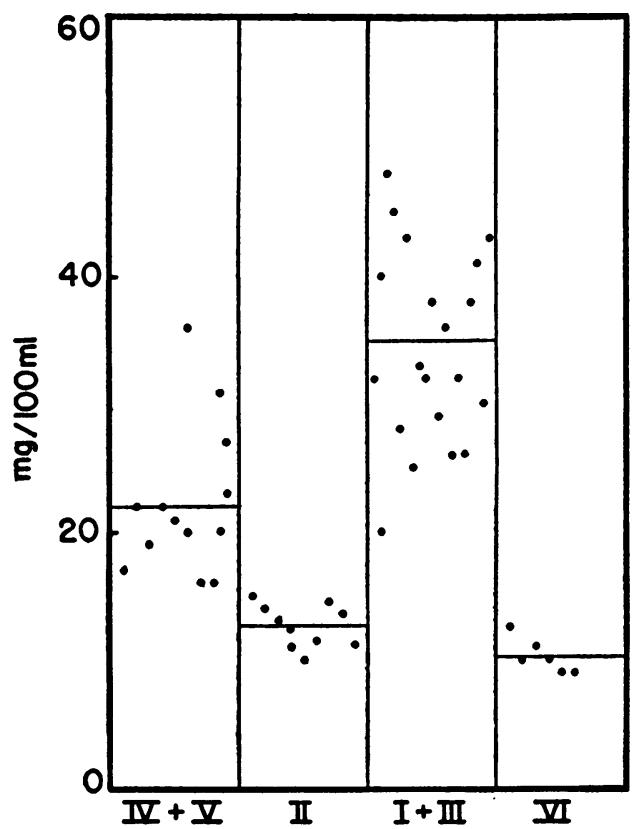

Fig. 4. Distribution of Protein-Bound Carbohydrate (Hexose) among the Fractions

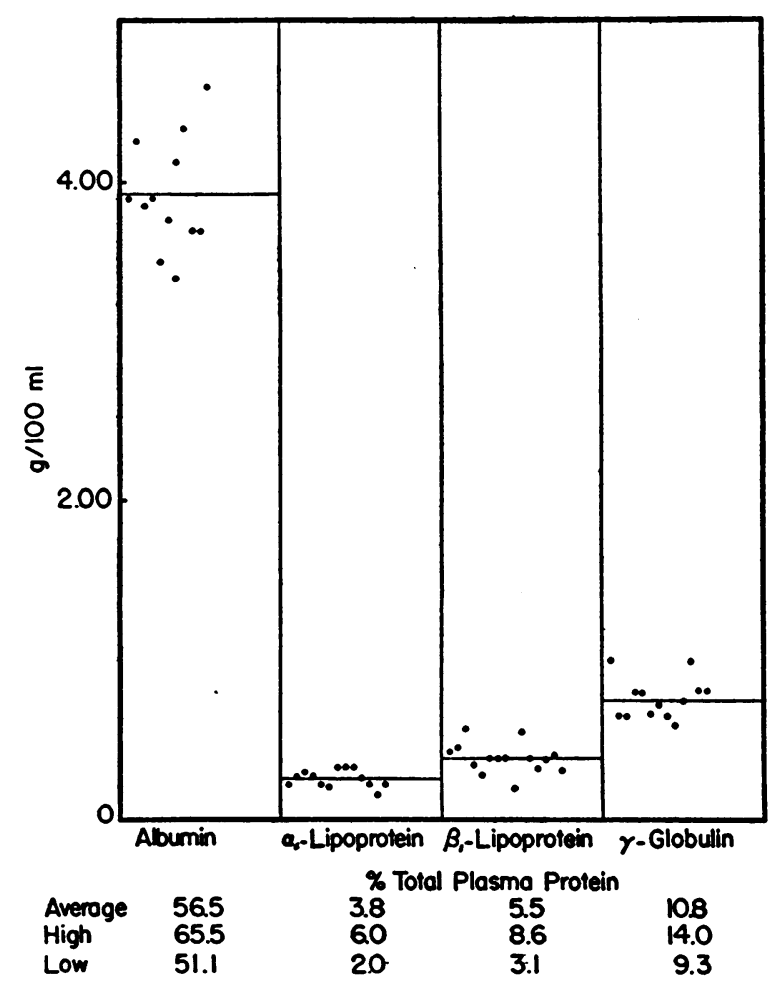

Fig. 5. Concentrations of Serux Albumins, $a$ LIPOPROTEINS, $\beta$-LIPOPROTEINS AND $\gamma$-GLOBULINS IN Plasma Determined by Chemical analysis of the Fractions 
exact quantities of hexose present in the complicated group of glycoproteins and mucoproteins of normal human plasma, coupled with the rather general distribution of protein-bound carbohydrate throughout the globulins in plasma (20), has made it impossible to interpret these data in a way similar to the lipid distributions (Figure 5). The data are presented as a useful definition of normal hexose distribution. The hexose in Fraction VI, normally combined principally with an $\alpha_{1}$-globulin described by Schmid (21), has been

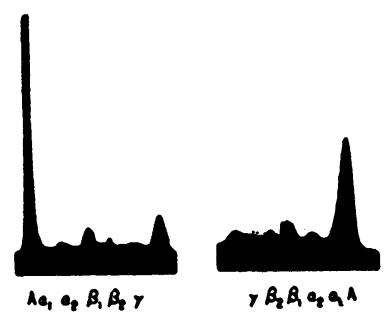

nORMAL human Plasma

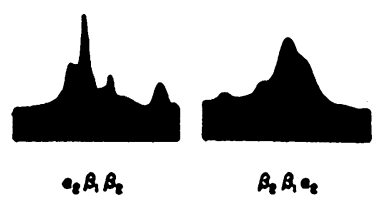

FRACTION I+III

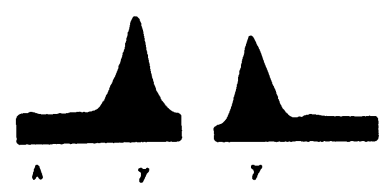

FRACTION II

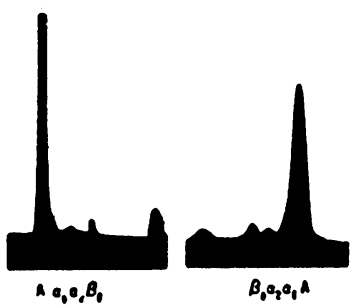

FRACTION $I+I$

Fig. 6. Electrophoretic Diagrams of Human Plasma and of Three of the Four Primary Fractions
TABLE II

Distribution of electrophoretic components in Fraction $I V+V$

\begin{tabular}{l|l|l|l|l|l|l|l}
\hline \hline & \multicolumn{7}{|c}{ Per cent of fraction } \\
\hline & $\begin{array}{c}\text { Albu- } \\
\text { min }\end{array}$ & $\alpha_{1}$ & $\alpha_{2}$ & $\beta_{1}$ & $\beta_{2}$ & $\begin{array}{c}\text { Fibrin- } \\
\text { ogen }\end{array}$ & $\gamma$ \\
\hline 85 & 7 & 2 & 5.5 & 0.5 & - & - \\
81 & 6 & 6 & 7 & - & - & - \\
80 & 10 & 4.5 & 5 & 0.5 & - & - \\
81 & 6 & 7 & 5 & 1 & - & - \\
84 & 5 & 4.5 & 6 & 0.5 & - & - \\
84 & 7 & 3 & 5 & 1 & - & - \\
82 & 6 & 5 & 6 & 1 & - & - \\
79 & 10 & 4 & 6 & 1 & - & - \\
84 & 7 & 3 & 6 & - & - & - \\
78 & 12 & 3.5 & 6 & 0.5 & - & - \\
79 & 8 & 9 & 3 & 1 & - & - \\
78 & 11 & 5 & 5 & 1 & - & - \\
Average & 81.3 & 7.8 & 4.7 & 5.5 & 0.7 & - & - \\
\hline
\end{tabular}

found to show marked increases in certain abnormal plasmas.

\section{Electrophoretic Composition of Fractions}

Typical electrophoretic composition data for Fractions IV + V, II, and I + III are presented in Figure 6 and in Tables II, III, and IV, respectively. The values for $\beta_{2}$-globulins in Table II are on the borderline of interpretation, and could have been included with the $\beta_{1}$-peak in the diagrams. Fraction IV $+\mathrm{V}$ separated on larger scales (2) was very rarely found to contain $\beta_{2}$-globulins.

Concentration of Serum Albumins, $\alpha$-Lipoproteins, $\beta$-Lipoproteins, $\gamma$-Globulins and Fibrinogen

The concentrations of serum albumins, $\alpha$-lipoproteins, $\beta$-lipoproteins, and $\gamma$-globulins are shown

TABLE III

Distribution of electrophoretic components in Fraction II

\begin{tabular}{l|c|c|c|c|c|c|c}
\hline \hline & \multicolumn{7}{|c}{ Per cent of fraction } \\
\hline \multirow{1}{*}{\begin{tabular}{c|c|c|c|c|c} 
Albu- \\
min
\end{tabular}} & $\alpha_{1}$ & $\alpha_{2}$ & $\beta_{1}$ & $\beta_{2}$ & $\begin{array}{c}\text { Fibrin- } \\
\text { ogen }\end{array}$ & $\gamma$ \\
\hline 6 & - & - & - & 4 & - & 90 \\
4 & - & - & - & 4 & - & 92 \\
4 & - & - & - & 4 & - & 92 \\
3 & - & - & - & 2 & - & 95 \\
5 & - & - & - & 3 & - & 92 \\
& - & - & - & - & 4 & - & 96 \\
& 1 & - & - & - & 3 & - & 96 \\
& 2 & 1 & - & - & 1 & - & 98 \\
& 5 & - & - & - & 8 & - & 92 \\
& 3.1 & 0.1 & - & - & 3.8 & - & 93.0 \\
\hline
\end{tabular}


in Figure 5, along with the percentages of the total plasma proteins which they represent. Serum albumins were determined by the hemin-binding method on Fraction IV $+\mathrm{V}$ rather than on whole plasma in order to avoid errors due to any nonspecific interference of other proteins.

The quantities of $\alpha$-lipoproteins and $\beta$-lipoproteins accord well with previous estimates $(22,16)$ based on fractionation studies of large pools of normal human plasma, and with the studies on individual sera reported by Gofman, Lindgren and Elliott (23).

In view of the rather satisfactory electrophoretic (Figure 6, Table III) purity of the $\gamma$-globulins in Fraction II, the total protein in Fraction II has been

TABLE IV

Distribution of electrophoretic components in Fraction $I+I I I$

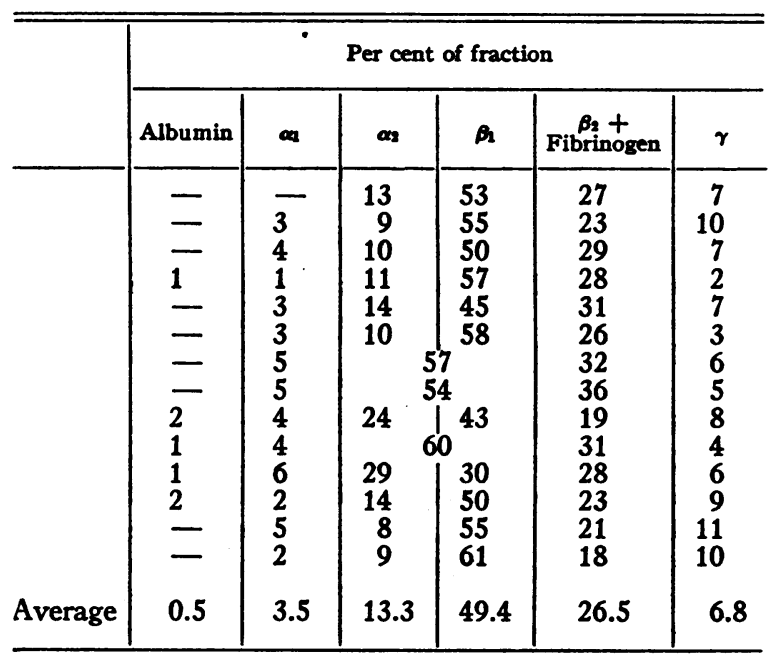

taken for the present purposes as a measure of the total $\gamma$-globulins of plasma. Data to be presented below concerning the distribution of added $\gamma$-globulin, along with considerable experience with pathological plasmas in which the $\gamma$-globulins were elevated, have confirmed the justification for this approximation.

In some of the early studies, fibrinogen was determined on Fraction I + III by the method employed by Morrison for the study of Fraction I (6). These determinations were discontinued because of extensive occlusion in the clot of the other proteins present in Fraction I + III, in confirmation of the findings of Morrison with Fraction III-0 euglobulin, a fraction also rich in $\beta$-lipoproteins (24). ${ }^{26}$ From previous studies on citrated plasma in this laboratory (25), using the method of Cullen and Van Slyke (26), a corrected average value of $0.28 \mathrm{~g}$. fibrinogen per $100 \mathrm{ml}$., or $4.04 \%$ of the total plasma proteins may be taken to supplement the data of the present series.

\section{Recovery of Added Plasma Proteins}

The recoveries in the separated fraction of added $\gamma$-globulins, $\beta$-metal combining protein and $\beta$-lipoproteins were studied. The $\gamma$-globulin preparation employed was prepared on a large scale by Method 10 (2) and was 99\% pure by electrophoresis, with albumin as the only impurity detected. The crystalline $\beta$-metal combining protein (27) and the purified $\beta$-lipoproteins (16) were isolated as previously described. Each protein was added in concentrated solution to one half of a sample of plasma so as to raise the concentration of the constituent to roughly twice the normal, leaving the other half as the control. Table $\mathrm{V}$ shows the increase in the various fractions calculated as per cent of the quantity of the constituent added.

The distribution of the added $\gamma$-globulins between Fractions II and I + III was as favorable as for normal concentrations. By electrophoretic analysis, $\gamma$-globulins remained absent from Fraction IV $+V$, and, as shown in Table VI, no significant changes occurred in the electrophoretic distribution of Fraction I + III.

\footnotetext{
26 A number of determinations of fibrinogen were made on separate samples of the plasma by the method of Morrison (6). The data were corrected on the assumption, based on an extrapolation of the data of Morrison, that occlusion of other proteins amounted to $40 \%$ of the weight of the fibrin. The range of values so obtained was $\mathbf{0 . 1 5}$ to $0.43 \mathrm{~g}$. per $100 \mathrm{ml}$., with an average of $0.30 \mathrm{~g}$. or $4.3 \%$ of the total plasma proteins.
}

TABLE V

Recovery of added plasma proteins

\begin{tabular}{c|c|c|c|c}
\hline \multicolumn{2}{c|}{ Protein added } & \multicolumn{2}{|c}{$\begin{array}{c}\text { Increase in fraction as per cent } \\
\text { 2dded constituent }\end{array}$} \\
\hline Nature & Conc. & IV + V & II & I + III \\
\hline & $8 . / 100$ ml. & & & \\
r-globulins & 0.60 & 0 & 93 & 10 \\
$\beta$-metal combining & 0.25 & 0 & 0 & 0 \\
$\begin{array}{c}\text { protein } \\
\text {-lipoproteins } \\
\text { (as cholesterol) }\end{array}$ & 0.39 & 0 & 0 & 92 \\
\hline
\end{tabular}


TABLE VI

Effect of addition of plasma proteins on electrophoretic composition of fractions

\begin{tabular}{|c|c|c|c|c|c|c|c|c|}
\hline \multirow[b]{2}{*}{ Protein added } & \multirow{2}{*}{$\begin{array}{l}\text { Fraction } \\
\text { analyzed }\end{array}$} & \multicolumn{7}{|c|}{ Per cent of fractions } \\
\hline & & & $\underset{\text { min }}{\text { Albu- }}$ & $\infty$ & $\infty$ & $\beta_{1}$ & $\left|\begin{array}{l}\beta_{2}+ \\
\mathrm{Fib}_{2}\end{array}\right|$ & $\boldsymbol{\gamma}$ \\
\hline $\begin{array}{l}\boldsymbol{\gamma} \text {-globulins } \\
\boldsymbol{\beta} \text {-metal comb. } \\
\text { protein } \\
\boldsymbol{\beta} \text {-lipoproteins }\end{array}$ & $\begin{array}{l}I+I I I \\
I V+V \\
I+I I I\end{array}$ & $\begin{array}{l}\text { Before } \\
\text { After } \\
\text { Before } \\
\text { After } \\
\text { Before } \\
\text { After }\end{array}$ & $\begin{array}{r}1 \\
4 \\
83 \\
78 \\
- \\
-\end{array}$ & $\begin{array}{l}7 \\
6 \\
9 \\
8 \\
6 \\
5\end{array}$ & $\begin{array}{r}6 \\
5 \\
3 \\
4 \\
5 \\
6\end{array}$ & $\begin{array}{l}5 \\
9 \\
8 \\
6\end{array}$ & $\begin{array}{l}25 \\
29 \\
\overline{-} \\
30 \\
21\end{array}$ & $\begin{array}{l}3 \\
4 \\
\\
6 \\
8\end{array}$ \\
\hline
\end{tabular}

The $\beta$-metal combining protein, due to the small amount added, failed to cause a change in the gross distribution of the proteins among the fractions (Table V). However, the electrophoretic data showed clearly the marked increase in $\beta_{1}$ globulins in Fraction IV + V (Table VI), whereas no changes were observed in the other fractions.

The recovery of $\beta$-lipoproteins in Fraction $\mathrm{I}+$ III, and the failure to contaminate the $\alpha$-lipoproteins in Fraction IV $+\mathrm{V}$, were striking. Table VI shows the absence of any significant increase in the small quantity of $\gamma$-globulins present in Fraction I + III.

These recovery experiments confirmed the selectivity of the separations, and showed that considerable increases in at least certain of the plasma proteins did not derange the system of fractionation. It was particularly important that large variations in the proportions of the strongly interacting components, $\gamma$-globulins and $\beta$-lipoproteins, could be tolerated in the separation of Fraction I + II + III and the subsequent extraction of Fraction II.

\section{SUMMARY}

1. Method 10 of plasma fractionation developed by Cohn and his co-workers has been adapted for the quantitative estimation of several protein and lipoprotein components in small quantities of normal human plasma.

2. In the system of analysis presented in this communication samples of $5 \mathrm{ml}$. of plasma were separated by filtration into four fractions and the amounts of albumin, $\gamma$-globulins, $\alpha$-lipoproteins and $\beta$-lipoproteins were determined. In addition, the distributions of cholesterol and phospholipid and of protein-bound carbohydrate (hexose) among the fractions were studied.
3. The proteins are present in the various fractions in an unaltered state. Their biologic activities are unimpaired and can be measured.

4. Of interest is the concentration in Fraction II of more than $90 \%$ of the $\gamma$-globulins of the plasma in a purity exceeding $90 \%$ by electrophoretic measurements. The other three fractions contain mixtures of unrelated proteins.

5. The plasma lipoproteins are divided into two primary groups; the $\alpha$-lipoproteins in Fraction IV $+\mathrm{V}$ contain a considerably higher proportion of phospholipids to cholesterol than the $\beta$-lipoproteins in Fraction I + III.

6. Added amounts of various pure proteins were in each case recovered in the appropriate fractions, proving that even large variations in the proportions of the various proteins do not interfere with the system of fractionation.

\section{ACKNOWLEDGMENT}

The authors wish to express their deep appreciation to Dr. Edwin J. Cohn for suggesting this investigation and for his advice and constructive criticism.

\section{REFERENCES}

1. Gutman, A. B., The plasma proteins in disease, in Advances in Protein Chemistry, edited by Anson, M. L., and Edsall, J. T. Academic Press, New York, 1948, Vol. IV, p. 156.

2. Cohn, E. J., Gurd, F. R. N., Surgenor, D. M., Barnes, B. A., Brown, R. K., Derouaux, G., Gillespie, J. M., Kahnt, F. W., Lever, W. F., Liu, C. H., Mittelman, D., Mouton, R. F., Schmid, K., and Uroma, E., A system for the separation of the components of human blood: quantitative procedures for the separation of the protein components of human plasma. J. Am. Chem. Soc., 1950, 72, 465.

3. Cohn, E. J., Strong, L. E., Hughes, W. L., Jr., Mulford, D. J., Ashworth, J. N., Melin, M., and Taylor, H. L., Preparation and properties of serum and plasma proteins. IV. A system for the separation into fractions of the protein and lipoprotein components of biological tissues and fluids. J. Am. Chem. Soc., 1946, 68, 459.

4. Edsall, J. T., The plasma proteins and their fractionation, in Advances in Protein Chemistry, edited by Anson, M. L., and Edsall, J. T. Academic Press, New York, 1947, Vol. III, p. 383.

5. Rosenfeld, M., and Surgenor, D. M., Methemalbumin; interaction between human serum albumin and ferriprotoporphyrin IX. J. Biol. Chem., 1950, $183,663$.

6. Morrison, P. R., Preparation and properties of serum and plasma proteins. XV. Some factors influencing the quantitative determination of fibrinogen. J. Am. Chem. Soc., 1947, 69, 2723. 
7. Mehl, J. W., The biuret reaction of proteins in the presence of ethylene glycol. J. Biol. Chem., 1945, $157,173$.

8. Bloor, W. R., Pelkan, K. F., and Allen, D. M., Determination of fatty acids (and cholesterol) in small amounts of blood plasma. J. Biol. Chem., 1922, 52, 191.

9. Fiske, C. H., and SubbaRow, Y., The colorimetric determination of phosphorus. J. Biol. Chem., $1925,66,375$.

10. Gortner, W. A., An evaluation of micromethods for phospholipid. J. Biol. Chem., 1945, 159, 97.

11. Rosenfeld, M., and Surgenor, D. M., in preparation.

12. Sørensen, M., and Haugaard, G., The application of the orcinol reaction to the estimation of the nature and amount of carbohydrate groups in proteins. Compt. rend. d. trav. du lab. Carlsberg, 1933, 19, No. $12,1$.

13. Friedmann, R., Characterization of sugar components of proteins. Biochem. J., 1949, 44, 117.

14. Armstrong, S. H., Jr., Budka, M. J. E., and Morrison, K. C., Preparation and properties of serum and plasma proteins. XI. Quantitative interpretation of electrophoretic schlieren diagrams of normal human plasma proteins. J. Am. Chem. Soc., 1947, 69, 416.

15. Armstrong, S. H., Jr., Budka, M. J. E., Morrison, K. C., and Hasson, M., Preparation and properties of serum and plasma proteins. XII. The refractive properties of the proteins of human plasma and certain purified fractions. J. Am. Chem. Soc., 1947, 69, 1747.

16. Oncley, J. L., Gurd, F. R. N., and Melin, M., Preparation and properties of serum and plasma proteins. XXV. Composition and properties of human serum $\beta$-lipoprotein. J. Am. Chem. Soc., 1950, 72, 458.

17. Gurd, F. R. N., Oncley, J. L., Edsall, J. T., and Cohn, E. J., The lipoproteins of human plasma. Discussions Faraday Soc., 1949, No. 6, 70.
18. Schoenheimer, R., and Sperry, W. M., A micromethod for the determination of free and combined cholesterol. J. Biol. Chem., 1934, 106, 745.

19. Pearsall, H. R., and Chanutin, A., I. Electrophoretic, nitrogen and lipide analyses of plasma and plasma fractions of healthy young men. Am. J. Med., 1949, 7, 297.

20. Surgenor, D. M., Strong, L. E., Taylor, H. L., Gordon, R. S., Jr., and Gibson, D. M., Separation of choline esterase, mucoprotein, and metal-combining protein into subfractions of human plasma. J. Am. Chem. Soc., 1949, 71, 1223.

21. Schmid, K., Preparation and properties of an acid glycoprotein prepared from human plasma. J. Am. Chem. Soc., 1950, 72, 2816.

22. Cohn, E. J., Chemical, physiological, and immunological properties and clinical uses of blood derivatives. Experientia, 1947, 3, 125.

23. Gofman, J. W., Lindgren, F. T., and Elliott, H., Ultracentrifugal studies of lipoproteins of human serum. J. Biol. Chem., 1949, 179, 973.

24. Oncley, J. L., Melin, M., Richert, D. A., Cameron, J. W., and Gross, P. M., Jr., The separation of the antibodies, isoagglutinins, prothrombin, plasminogen and $\beta_{1}$-lipoprotein into subfractions of human plasma. J. Am. Chem. Soc., 1949, 71, 541.

25. Edsall, J. T., Ferry, R. M., and Armstrong, S. H., Jr., Chemical, clinical, and immunological studies on the products of human plasma fractionation. XV. The proteins concerned in the blood coagulation mechanism. J. Clin. Invest., 1944, 23, 557.

26. Cullen, G. E., and Van Slyke, D. D., Determination of the fibrin, globulin and albumin nitrogen of blood plasma. J. Biol. Chem., 1920, 41, 587.

27. Surgenor, D. M., Koechlin, B. A., and Strong, L. E., Chemical, clinical, and immunological studies on the products of human plasma fractionation. XXXVIf. The metal-combining globulin of human plasma. J. Clin. Invest., 1949, 28, 73. 